\title{
Serum CD4 is associated with the infiltration of CD4+T cells in the tumor microenvironment of gastric cancer
}

\author{
Qi You ${ }^{1}$, Tianyi Fang ${ }^{1}$, Xin Yin ${ }^{1}$, Yimin Wang ${ }^{1}$, Yongheng Yang ${ }^{2}$, Lei Zhang ${ }^{2}$, and Yingwei \\ $\mathrm{Xue}^{1}$ \\ ${ }^{1}$ Harbin Medical University Third Hospital \\ ${ }^{2}$ Harbin Medical University
}

May 5, 2020

\begin{abstract}
Serum CD4, CD8 and CD19 are markers of systemic inflammation. However, there is little evidence on the influence of inflammation on the tumor microenvironment and the prognostic indicators of gastric cancer (GC). In this study, two hundred and eight patients who underwent radical gastrectomy for GC were included. Preoperative peripheral blood samples were used to analyze serum CD4, CD8 and CD19. The optimal cutoff levels for CD4, CD8 and CD19 were defined by receiver operating characteristic curve analysis $(\mathrm{CD} 4=38.85 \%, \mathrm{CD} 8=14.35 \%$ and $\mathrm{CD} 19=7.40 \%)$. The areas with specific CD4+T cells, CD $8+\mathrm{T}$ cells and CD19+B cells within the tumor microenvironment were measured in paraffin sections by immunohistochemistry and analyzed by Image-Pro Plus. 94 patients had low CD4 and 124 patients had high CD4 levels. 31 patients had low CD8 and 187 patients had high CD8 levels. 64 patients had low CD19 and 154 patients had high CD19 levels. Infiltration of CD4+T cells was associated with serum CD4 $(\mathrm{P}<0.001)$. Serum CD4, CD19, and the infiltration of CD4+T cells, CD8+T cells, and CD19+B cells were significant in predicting the prognosis of GC. Low CD4 level, infiltration of CD8+T cells and high infiltration of CD4+T cells and CD19+B cells were correlated with worse overall survival in multivariate analysis. Collectively, our results provide evidence that serum CD4 is associated with the infiltration of CD4+T cells in the tumor microenvironment, which indicates the prognostic value of systemic inflammation in GC.
\end{abstract}

\section{Serum CD4 is associated with the infiltration of $\mathrm{CD}^{+} \mathrm{T}$ cells in the tumor microenvironment of gastric cancer}

Short title: Serum CD4 is associated with the infiltration of CD4+T cells

Qi You ${ }^{1 \#}$, Tianyi Fang ${ }^{1 \#}$, Xin Yin ${ }^{1}$, Yimin Wang ${ }^{1}$, Yongheng Yang ${ }^{2}$, Lei Zhang ${ }^{2}$, Yingwei Xue ${ }^{*}$

1 Department of Gastrointestinal Surgery, Harbin Medical University Cancer Hospital, Harbin Medical University, Harbin, Heilongjiang 150086, P.R. China.

${ }^{2}$ Department of Pathology, Harbin Medical University, Harbin, Heilongjiang 150001, P.R. China.

\# Contributed equally

Correspondence should be addressed to Yingwei Xue; xueyingwei@hrbmu.edu.cn, Telephone: $+8613304646901$

Keywords:

Gastric cancer; $\mathrm{CD} 4^{+} \mathrm{T}$ cells; Systemic inflammation; Tumor microenvironment; Prognosis

Abbreviations list: 
GC: Gastric cancer

TNM-I: TNM-immune

UICC: Union for International Cancer Control

NLR: Neutrophil-lymphocyte ratio

PLR: Platelet-lymphocyte ratio

AJCC: American Joint Committee on Cancer

OS: Overall survival

HR: hazard ratio

DAB: diaminobenzidine

TCGA: The Cancer Genome Atlas

EBV: Epstein-Barr virus

MSI: Microsatellite Instability

GS: Genomically Stable

CIN: Chromosomal Instability

CT: Computed Tomography

MRI: Magnetic Resonance Imaging

ECG: Electrocardiogram

PET: Positron emission tomography

PD-L1; Programmed cell death-Ligand 1

\section{Summary}

Serum CD4, CD8 and CD19 are markers of systemic inflammation. However, there is little evidence on the influence of inflammation on the tumor microenvironment and the prognostic indicators of gastric cancer (GC). In this study, two hundred and eight patients who underwent radical gastrectomy for GC were included. Preoperative peripheral blood samples were used to analyze serum CD4, CD8 and CD19. The optimal cutoff levels for CD4, CD8 and CD19 were defined by receiver operating characteristic curve analysis $(\mathrm{CD} 4=38.85 \%, \mathrm{CD} 8=14.35 \%$ and $\mathrm{CD} 19=7.40 \%)$. The areas with specific CD4 ${ }^{+} \mathrm{T}$ cells, $\mathrm{CD} 8^{+} \mathrm{T}$ cells and $\mathrm{CD} 19^{+} \mathrm{B}$ cells within the tumor microenvironment were measured in paraffin sections by immunohistochemistry and analyzed by Image-Pro Plus. 94 patients had low CD4 and 124 patients had high CD4 levels. 31 patients had low CD8 and 187 patients had high CD8 levels. 64 patients had low CD19 and 154 patients had high CD19 levels. Infiltration of $\mathrm{CD} 4^{+} \mathrm{T}$ cells was associated with serum CD4 $(P<0.001)$. Serum CD4, CD19, and the infiltration of $\mathrm{CD} 4^{+} \mathrm{T}$ cells, $\mathrm{CD} 8^{+} \mathrm{T}$ cells, and $\mathrm{CD} 19^{+} \mathrm{B}$ cells were significant in predicting the prognosis of GC. Low CD4 level, infiltration of $\mathrm{CD} 8^{+} \mathrm{T}$ cells and high infiltration of $\mathrm{CD} 4^{+} \mathrm{T}$ cells and $\mathrm{CD} 19^{+} \mathrm{B}$ cells were correlated with worse overall survival in multivariate analysis. Collectively, our results provide evidence that serum CD4 is associated with the infiltration of CD4 ${ }^{+} \mathrm{T}$ cells in the tumor microenvironment, which indicates the prognostic value of systemic inflammation in GC.

\section{Introduction}

According to the latest global cancer report, more than $70 \%$ of new cases of gastric cancer (GC) and deaths are from developing countries, causing a social burden that cannot be ignored $[1,2]$. Recent years, immunotherapy is proving to be an effective therapeutic method in a variety of cancers, but researchers have realized that the effects of immunotherapy often vary greatly from individual to individual $[3,4]$. In patients 
with pathological response of tumor regression or no response, the 5-year survival rate differs by more than $50 \%$ [5-7]. Therefore, in addition to providing standardized treatment for patients, it is also necessary for clinicians to identify sensitive, easily available, and low-cost markers to provide a basis for individualized treatment and prediction of prognosis in GC patients.

Chronic local inflammation has been shown to play an important role in tumorigenesis and progression. Inflammatory cells are also considered to be an important part of the tumor microenvironment [8, 9]. Pathologists have noted that tumor-associated neutrophils, tumor-associated macrophages, and tumor-associated lymphocytes exist in the microenvironment of various malignancies [10]. From 2013 to 2018, Galon [11, 12] first proposed the incorporation of TNM-I (TNM-immune) into the tumor staging criteria, and the Union for International Cancer Control (UICC) included the degree of infiltration of immune cells in tumor microenvironment into the pathological staging of colon cancer [13]. The predictive effect of tumor-associated immune cells on the prognosis of patients has been a hot research topic worldwide. Recent researches have shown that tumor-infiltrating lymphocytes can be used as predictive biomarkers for immunotherapy sensitivity in patients with liver cancer $[14,15]$. These studies have indicated that inflammatory cells in the tumor microenvironment can not only classify patients into pathological stages, but also play a valuable predictive role in the response to cancer immunotherapy.

The systemic chronic inflammatory response is also thought to be associated with tumor prognosis. These predictors include the neutrophil-lymphocyte ratio (NLR), platelet-lymphocyte ratio (PLR), C-reactive protein and procalcitonin. Many studies have shown that these markers are independent factors in the prognosis of patients with lung cancer [16], liver cancer [17], pancreatic cancer [18], and colon cancer [19]. In 2017, Choi [20] first reported that the NLR and PLR were associated with the density of immune cells in the tumor microenvironment, which leads to prognostic values of systemic inflammation in gastric cancer. However, the main limitation of this kind of researches, which aimed to reflect the systemic inflammatory response by using this ratio, was that it could not accurately reflect the changing characteristics of immune cell subsets [21]. This difference in subsets such as CD4, CD8, and CD19 cells affects the sensitivity and effectiveness of immunotherapy more precisely, but there are still no other comprehensive researches to clarify this phenomenon.

At present, the infiltration of immune cells in the tumor microenvironment can only be evaluated using pathological sections and microscopy. But due to the high heterogeneity of GC, there is a great variety of randomness in the choice of pathological section and observation field, which result in difficulties in terms of clinical application [11]. A variety of cytokines and inflammatory cells are currently known to migrate from peripheral blood into tumor microenvironment mainly through the systemic circulation [22]. Thus, whether peripheral blood with a controllable detection level can reflect the infiltration of immune cells in tumor microenvironment is worth further study.

In the present study, we investigated the prognostic value of $\mathrm{CD} 4^{+} \mathrm{T}$ cells, $\mathrm{CD} 8^{+} \mathrm{T}$ cells, and $\mathrm{CD} 19^{+} \mathrm{B}$ cells in peripheral blood by flow cytometry as well as in the tumor microenvironment by immunohistochemistry of GC, and evaluated their correlations in different locations in order to determine their complicated interactions.

\section{Materials and Methods}

Patients

A total of 218 patients with GC were randomly selected from August 2014 to June 2015 in the Department of Gastrointestinal Surgery, Harbin Medical University Cancer Hospital. The diagnosis of GC was based on the pathological report following gastroscopy. All patients received D2 lymphadenectomy and the specimens were pathologically examined. The included patients underwent abdominal ultrasound, stomach CT / MRI, chest film, ECG and other examinations, and some patients underwent PET-CT scanning. The patients were staged according to the American Joint Committee on Cancer (AJCC)/UICC 8th edition staging system. The exclusion criteria were as follows: (a) preoperative radiotherapy or chemotherapy, (b) distant metastasis, (c) recurrent GC, or the presence of another tumor, (d) antiplatelet therapy within the previous three months, 
(e) septicemia or severe systemic infection (f) patients with blood disorders or multiple myeloma and (g) medical records were incomplete. All patients were followed up after discharge. The median follow-up time was 42 months (range 0-60 months). The medical records were included in the GC Information Management System version 1.2 (Copyright No. 2013SR087424) of Harbin Medical University Cancer Hospital. This study was approved by the Ethics Committee of Harbin Medical University.

Laboratory examinations

Peripheral blood samples were collected from patients within 3 days before surgery for routine laboratory examination to determine the leukocyte count, neutrophil count, lymphocyte count, and levels of serum CD4, CD8 and CD19. According to the receiver operating characteristic curve, an optimal threshold value was defined in order to divide the samples into two groups (high group and low group) in relation to the inflammatory markers.

Density of immune cells in the tumor microenvironment

Immune cells in the tumor microenvironment were analyzed by immunohistochemistry using paraffin sections. Tissue samples from surgical specimens were fixed in $10 \%$ formalin for 48 hours and then embedded in paraffin. Paraffin sections from the 218 GC patients were dewaxed in xylene and ethanol. After cleaning in distilled water, the paraffin sections were pretreated with citrate buffer at pH 8.0 (CD4, CD8 and CD19) for $3 \mathrm{~min}$ at $120^{\circ} \mathrm{C}$ in a pressure cooker, and endogenous peroxidase was inhibited with $3 \% \mathrm{H} 2 \mathrm{O} 2$ in PBS for $10 \mathrm{~min}$. Nonspecific actions in the sections were also blocked with goat serum (BOSTER, Pleasanton, CA, USA) for 1 hour at room temperature. The sections were then incubated with the primary antibody overnight at $4^{\circ} \mathrm{C}$ and for 30 min with the secondary antibody at $37^{\circ} \mathrm{C}$. The primary antibodies used were CD4 (ab183685, 1: 1000, Abcam, Cambridge, MA, USA), CD8 (ab4055, 1: 100, Abcam, Cambridge, MA, USA), and CD19 (ab134114, 1: 300, Abcam, Cambridge, MA, USA). The secondary antibody was goat anti-rabbit IgG (CD4, CD8, CD19). The chromogenic reaction was performed via diaminobenzidine (DAB) staining, and the staining intensity was measured using Image-Pro Plus version 6.2 software (Media Cybernetics, Rockville, MD, USA).

All specimens were reviewed by two independent blinded pathologists based on the percentage of positively stained cells. In order to minimize the heterogeneity of immune cell distribution, a series of optimization experiments were performed to reduce subjective factors. The pathologists carefully examined hematoxylin and eosin $(\mathrm{H} \& \mathrm{E})$ staining of multiple wax blocks from the same patient sample before the experiment without knowing the identity of the patients. The most representative wax block covering multiple heterogeneous regions was selected for the experiment using the same criteria. In order to reduce the effect of heterogeneity, image information was collected from lymphocyte-enriched regions, interstitial regions and tumor-cell-enriched regions, respectively, and the average area was estimated by relative percentage staining and intensity staining. Three representative images with a magnification of $\times 200$ were collected, and the area of immunostaining in each image was measured using Image-Pro Plus version 6.2 software. In addition, all enrolled patients did not receive preoperative chemotherapy and radiotherapy, thus eliminating the effects of chemotherapy and radiotherapy on tumor cells and immune cells.

Statistical analysis

Differences in serum CD4, CD8 and CD19 levels were assessed by the Chi-square test. Correlation coefficients were calculated by the $\mathrm{T}$ test or Pearson correlation analysis to assess the correlation between serum inflammatory markers and the percentage of immune cells in the tumor microenvironment. Overall survival (OS) was determined from the date of surgery to the date of the last follow-up or death of any cause. The Kaplan-Meier method was used to calculate the survival rate, and the log-rank test was used for statistical analysis. Multivariate analysis of prognostic factors was performed using the Cox proportional hazard model. A $P$ value less than 0.05 was considered statistically significant. Statistical analysis was performed using SPSS 22.0 (Chicago, IL, USA).

\section{Results}




\section{Patient characteristics}

Of the 218 patients, $166(76.1 \%)$ were men, and 52(23.9\%)were women. There were 38 elderly patients (over 70 years), accounting for $17.4 \%$. All patients underwent major gastrectomy. According to the Borrmann classification, $40.8 \%$ of the patients were of Borrmann type III (40.8\%) and $17.4 \%$ were of Borrmann type I. $39.4 \%$ of the patients showed vascular infiltration, and $62.4 \%$ of the patients showed nerve invasion. According to the 8th edition of the AJCC staging system, stage I patients accounted for 17.9\%, stage II patients for $26.6 \%$, stage III patients for $49.1 \%$, and stage IV patients for $6.4 \%$. With regard to lymph node involvement, lymph nodes were negative in $66(30.3 \%)$ patients, and the lymph node ratio (ratio of the number of invaded lymph nodes to the number of lymph nodes examined) was between $85.0 \%$ and $39.0 \%$. Forty-four (20.2\%) patients had a lymph node ratio between 0.3 and 0.6 , and 23 (10.6\%) patients had a lymph node ratio greater than 0.6. With regard to tumor location, entire stomach GC accounted for 7.3\%, upper third GC for 8.3\%, middle third GC for 18.8\%, and lower third GC for 65.6\% (Table 1).

Relationship between clinical pathology and blood inflammatory markers

Median serum CD4 was 40.1\% (range 19.4\%-66.2\%), and we defined $38.85 \%$ as the cut-off value. Ninety-four patients were in the low CD4 group and 124 patients were in the high CD4 group. Median serum CD8 was $22.57 \%$ (range $4.4 \%-56.5 \%$ ), and we defined $14.35 \%$ as the cut-off value. Thirty-one patients were in the low CD8 group and 187 patients were in the high CD8 group. Median serum CD19 was 9.7\%, and we defined $7.40 \%$ as the cut-off value. Sixty-four patients were in the low CD19 group and 154 patients were in the high CD19 group.

Serum CD4 was found to be associated with Borrmann classification and lymph node metastasis, while serum CD4 and CD19 were associated with age. The lower levels of CD4 $(P=0.024)$ and CD19 $(P=0.020)$ were more common in patients younger than 70 years, and higher Borrmann type and lymph node metastasis were related to increased serum CD4 $(P=0.041, P=0.026$, Table 2).

Survival analysis in relation to serum inflammatory markers and immune cell infiltration of the tumor microenvironment

Figure 2 shows the representative immunohistochemistry of immune cells (Figure 2A: high infiltration of $\mathrm{CD} 4^{+} \mathrm{T}$ cells; Figure 2B: low infiltration of $\mathrm{CD} 4^{+} \mathrm{T}$ cells; Figure $2 \mathrm{C}$ : high infiltration of $\mathrm{CD} 8^{+} \mathrm{T}$ cells; Figure 2D: low infiltration of $\mathrm{CD}^{+} \mathrm{T}$ cells; Figure $2 \mathrm{E}$ : high infiltration of $\mathrm{CD} 19^{+} \mathrm{B}$ cells; Figure $2 \mathrm{~F}$ : low infiltration of $\mathrm{CD} 19^{+} \mathrm{B}$ cells). By analyzing the level of serum inflammatory markers and the prognosis of patients, we found that the 5-year OS rate of patients with high serum CD4 was better than that of patients with low serum CD4 (Fig. 1A), and was $48.5 \%$ and $21.8 \%$, respectively. The 5-year OS rate of patients with high serum CD8 was better than that of patients with low serum CD8 (Fig. 1B), and was 37.6\% and 32.1\%, respectively. The 5-year OS rate of patients with high serum CD19 was better than that of patients with low serum CD19 (Fig. 1C), and was $41.4 \%$ and $26.6 \%$, respectively.

By analyzing immune cell infiltration in the tumor microenvironment and prognosis, we found that the 5-year OS rate in the group with high $\mathrm{CD} 4^{+} \mathrm{T}$ cell infiltration was lower than that in the group with low $\mathrm{CD} 4{ }^{+} \mathrm{T}$ cell infiltration (Fig. 3A), and was $9.1 \%$ and $60.4 \%$, respectively. The 5-year OS rate in the group with high $\mathrm{CD}^{+} \mathrm{T}$ cell infiltration was better than that in the group with low $\mathrm{CD} 8^{+} \mathrm{T}$ cell infiltration (Fig. 3B), and was $57.5 \%$ and $12.4 \%$, respectively. The 5-year OS rate in the group with high CD $19^{+} \mathrm{B}$ cell infiltration was lower than that in the group with low $\mathrm{CD} 19^{+} \mathrm{B}$ cell infiltration (Fig. 3C), and was $3.7 \%$ and $65.1 \%$, respectively. Compared with the level of immune cells in peripheral blood and the infiltration of immune cells in the tumor microenvironment, CD $4^{+} \mathrm{T}$ cells and $\mathrm{CD} 19^{+} \mathrm{B}$ cells showed the opposite trend in peripheral blood and in the tumor microenvironment.

Univariate analysis showed that serum CD4 (HR 0.490, 95\% CI 0.342-0.701, $P<0.001$ ), serum CD19 (HR 0.644, 95\% CI 0.445-0.932, $P=0.020)$, CD4 ${ }^{+} \mathrm{T}$ cell infiltration (HR 6.502, 95\% CI 4.191-10.086, $P<0.001$ ), $\mathrm{CD}^{+} \mathrm{T}$ cell infiltration (HR 0.201, 95\% CI 0.135-0.301, $P<0.001$ ) and $\mathrm{CD} 19^{+} \mathrm{B}$ cell infiltration (HR 6.104, 95\% CI 4.000-9.315, $P<0.001)$ were associated with prognosis. Multivariate analysis showed that serum 
CD4 and immune cell infiltration in the tumor microenvironment were independent prognostic factors in the OS multivariate model: serum CD4 (HR 0.674, 95\% CI 0.466-0.973, $P=0.035$ ), CD4 ${ }^{+} \mathrm{T}$ cell infiltration (HR $3.354,95 \%$ CI 2.131-5.276, $P<0.001$ ), CD8 ${ }^{+}$T cell infiltration (HR 0.455, 95\% CI 0.289-0.716, $P=0.001$ ), and CD19 ${ }^{+} \mathrm{B}$ cell infiltration (HR 3.062, 95\% CI 1.910-4.907, $P<0.001$ ) (Table 3).

Relationship between the levels of serum inflammation and tumor infiltrating immune cells

The percentage of infiltrated area of $\mathrm{CD}^{+} \mathrm{T}$ cells, $\mathrm{CD} 8^{+} \mathrm{T}$ cells, and $\mathrm{CD} 19^{+} \mathrm{B}$ cells in the tumor microenvironment was $3.42 \%+-1.08 \%, 1.76 \%+-0.96 \%$, and $4.16 \%+-2.20 \%$, respectively. The percentage of $\mathrm{CD} 4^{+} \mathrm{T}$ cell infiltrated area was $3.11 \%+-1.21 \%$ and $3.68 \%+-1.16 \%$ in the high serum CD4 group and the low serum CD4 group, respectively. The percentage of $\mathrm{CD} 8^{+} \mathrm{T}$ cell infiltrated area was $1.99 \%+-1.02 \%$ and $1.93 \%+-0.98 \%$ in the high serum CD8 group and the low serum CD8 group, respectively. The percentage of infiltrated area of CD19+ $\mathrm{B}$ cell in the high serum CD19 group and low serum CD19 group was 5.03\% +$3.43 \%$ and $4.07 \%+-2.47 \%$, respectively. Pearson correlation coefficient analysis showed that serum CD4 levels were correlated with $\mathrm{CD} 4^{+} \mathrm{T}$ cell infiltration in the tumor microenvironment (correlation coefficient $=$ $-0.209, P<0.005$, Fig. 4 A), but CD8 and CD19 did not show this trend (correlation coefficient $=-0.088, P$ $=0.197$, Fig. $4 \mathrm{~B}$; correlation coefficient $=-0.101, P=0.138$, Fig. $4 \mathrm{C})$.

\section{Discussion}

GC is a common malignant digestive system tumor with a high incidence and short survival period in China [23]. Almost 50\% of new GC cases worldwide were from China and more than $60 \%$ were at an advanced stage [24]. Surgery is also the key treatment in advanced GC, but the effect is always limited. More than half of patients with advanced GC who only received surgery relapsed within months to two years [25]. Therefore, the surgical treatment without adjuvant therapy can not significantly improve survival probability. In recent years, with continued understanding of the molecular biological characteristics of GC, immunotherapy as a new tumor treatment option, has achieved significant results in the treatment of melanoma [26] and hematological tumors [27], and has shown great potential in the clinical treatment of advanced GC [28]. Immunotherapy mainly includes Natural Immunotherapy, Tumor Vaccine Therapy, Adoptive Immunotherapy and Immune Checkpoint Inhibitor Therapy [29].

In a study of Pembrolizumab in the treatment of PD-L1 positive patients with advanced GC, $53 \%$ of patients had tumor regression, $22 \%$ achieved partial remission imaging, and the safety was better than secondline chemotherapy [30]. However, because of the individual differences in drug sensitivity and side effects during immunotherapy for GC, there are no objective parameters in clinical practice to help the preliminary screening of sensitive patients. In 2014, The Cancer Genome Atlas (TCGA) proposed a new molecular typing of GC for the first time, including Epstein-Barr virus (EBV) positive, Microsatellite Instability (MSI), Genomically Stable (GS) and Chromosomal Instability (CIN), which is conducive to the screening of targeted drugs for individualized treatment of GC [13]. However, to date, there are still no reliable biomarkers to predict the efficacy of these immunotherapies and the long-term survival probability.

The present study found that serum CD4 and CD19 as biomarkers of systemic inflammation had better prognostic value for GC. It was also found that the level of inflammatory cell infiltration in tumor microenvironment, including $\mathrm{CD} 4^{+} \mathrm{T}$ cells, $\mathrm{CD} 8^{+} \mathrm{T}$ cells and $\mathrm{CD} 19^{+} \mathrm{B}$ cells, was of certain significance in predicting the prognosis of GC. In particular, the change in serum CD4 was correlated with the infiltration of CD4 ${ }^{+} \mathrm{T}$ cells in the tumor microenvironment. This indicated that the analysis of peripheral blood can be used to assess immune cell infiltration in the tumor microenvironment. This information may be valuable in selecting patients with GC who may benefit from immunotherapy.

Previous studies have shown that immune cell infiltration in the tumor microenvironment has prognostic value in many types of cancer, which is similar to our findings [31]. However, few studies have evaluated the association between prognosis, the tumor microenvironment, and systemic inflammatory response. We pointed out that a low serum CD4 level or increased $\mathrm{CD} 4^{+} \mathrm{T}$ cell infiltration in the GC microenvironment can predict a poor prognosis, and this may be related to the function of $\mathrm{CD} 4^{+} \mathrm{T}$ cells in peripheral blood. Serum $\mathrm{CD} 4^{+} \mathrm{T}$ cells can target cancer cell surface antigens and activate peripheral blood $\mathrm{CD} 8^{+} \mathrm{T}$ cells to 
enter the tumor microenvironment, which can activate the function of killing cancer cells [32, 33]. Moreover, our research also found that increased $\mathrm{CD} 8^{+} \mathrm{T}$ cell infiltration in the tumor microenvironment often indicates a good prognosis, which may explain this phenomenon.

The main function of peripheral blood $\mathrm{CD} 19^{+} \mathrm{B}$ cells is to secrete immunoglobulins (including IgG, IgA, $\operatorname{IgM}, \operatorname{IgD}, \operatorname{IgE}$ ) in order to exert humoral immune functions [34]. In the peripheral blood of patients with GC, B cells can regulate their own functions and release inflammatory factors to inhibit $\mathrm{T}$ cells and natural killer T cells so as to play an anti-tumor role [35]. The reason why CD19+ B cells in tumor microenvironment indicate a poor prognosis, which is not consistent with the function of peripheral blood, can be explained by the following mechanism. In 2019, Gu [36] demonstrated that tumor cells can "domesticate" B cells to promote lymph node metastasis in breast cancer. Humoral immunity mediated by tumor-educated B cells and their derived antibodies plays an important role in lymph node premetastatic niche formation. The ability of B cells to secrete antibodies (especially $\operatorname{IgG}$ ) was significantly enhanced, and the pathogenic IgG could specifically target glycosylated membrane protein HSPA4, which could directly promote tumor metastasis by activating the HSPA4-binding protein ITGB5 and the downstream Src/NF- $x$ B pathway. This may also explain why B cells in the peripheral blood of GC patients have different functions from those infiltrating the tumor microenvironment. GC cells can "domesticate" peripheral blood B cells and humoral immunity contributes to the progression of cancers. When B cells enter the tumor microenvironment, they interact with tumor cells to promote cancer development. However, this conjecture requires further functional tests for verification.

In addition, this study also found that serum CD4 and CD19 were significantly different in GC patients of different ages, and the levels of these two immune cells were higher in patients aged over 70 years. It can be seen that with increasing age, the human immune system changes markedly. There is effect of aging on cells of the immune system, on soluble molecules, on lymphoid organs and the initiation of immune responses [37]. Moreover, some individuals arrive to advanced ages without any major health problems, called healthy aging. The immune system dysfunction seems to be somehow mitigated in this population [38]. This indicates that clinical immunotherapy requires evaluation of the immune status of patients in combination with their age, which will be helpful in screening out drug sensitive patients.

Based on our findings, there is a correlation between serum inflammatory markers and immune cell infiltration in the tumor microenvironment. Thus, we propose that serum CD4 can be used to evaluate immune status in the tumor microenvironment. These markers can be easily obtained from peripheral blood without invasive tissue biopsy. This type of inflammatory marker in peripheral blood is also expected to evaluate the efficacy of immunotherapy in patients with GC.

However, this study has some limitations. First, different subtypes of $\mathrm{T}$ cells and B cells were not randomly distributed. Tumor-infiltrating immune cells appear in different parts of the tumor microenvironment such as in the center of the tumor, at the invasive margin of tumoral nests and in adjacent tertiary lymphoid structures, and may have different functions [11]. Therefore, the role of different subtypes and different infiltration areas of immune cells requires further investigations. When performing peripheral blood tests, the detection of CD4 and CD8 double positive immune cells is unavoidable, which may have had an impact on our conclusions. Second, it may not be possible to completely rule out systemic inflammatory reactions not caused by cancer, such as those caused by pneumonia, gastritis, Helicobacter pylori infection and autoimmune diseases.

In conclusion, our research shows that the systemic inflammatory markers, serum CD4 and CD19, and tumor infiltrating cells of $\mathrm{CD} 4^{+} \mathrm{T}, \mathrm{CD} 8^{+} \mathrm{T}$ and $\mathrm{CD} 19^{+} \mathrm{B}$ can predict the prognosis of GC patients. In addition, the level of serum CD4 is related to the infiltration of $\mathrm{CD}^{+} \mathrm{T}$ cells in the tumor microenvironment. This systemic inflammatory marker in peripheral blood is expected to predict the prognosis of GC patients and sensitivity to immunotherapy.

\section{Conflict of Interest}

The authors declare that they have no conflicts of interest. 


\section{Acknowledgments}

This study was supported by the Nn10 program of Harbin Medical University Cancer Hospital (Nn10PY201703) from Yingwei Xue. We thank all doctors and patients who provide data on the Gastric Cancer Information Management System v1.2. Qi You, Tianyi Fang and Yingwei Xue designed and conceived this project; Tianyi Fang, Yimin Wang and Xin Yin analysised the data; Yingwei Xue and Qi You revised the manuscript for important intellectual content; Qi You, Tianyi Fang, Yongheng Yang and Xin Yin collated the data; Tianyi Fang, Yimin Wang, Yongheng Yang, Lei Zhang performed immunohistochemistry experiments.

\section{References}

1. Global Burden of Disease Cancer C, Fitzmaurice C, Allen C, Barber RM, Barregard L, Bhutta ZA, Brenner H, Dicker DJ, Chimed-Orchir O, Dandona R, Dandona L, Fleming T, Forouzanfar MH, Hancock J, Hay RJ, Hunter-Merrill R, Huynh C, Hosgood HD, Johnson CO, Jonas JB, Khubchandani J, Kumar GA, Kutz M, Lan Q, Larson HJ, Liang X, Lim SS, Lopez AD, MacIntyre MF, Marczak L, Marquez N, Mokdad AH, Pinho C, Pourmalek F, Salomon JA, Sanabria JR, Sandar L, Sartorius B, Schwartz SM, Shackelford KA, Shibuya K, Stanaway J, Steiner C, Sun J, Takahashi K, Vollset SE, Vos T, Wagner JA, Wang H, Westerman R, Zeeb H, Zoeckler L, Abd-Allah F, Ahmed MB, Alabed S, Alam NK, Aldhahri SF, Alem G, Alemayohu MA, Ali R, Al-Raddadi R, Amare A, Amoako Y, Artaman A, Asayesh H, Atnafu N, Awasthi A, Saleem HB, Barac A, Bedi N, Bensenor I, Berhane A, Bernabe E, Betsu B, Binagwaho A, Boneya D, Campos-Nonato I, Castaneda-Orjuela C, Catala-Lopez F, Chiang P, Chibueze C, Chitheer A, Choi JY, Cowie B, Damtew S, das Neves J, Dey S, Dharmaratne S, Dhillon P, Ding E, Driscoll T, Ekwueme D, Endries AY, Farvid M, Farzadfar F, Fernandes J, Fischer F, TT GH, Gebru A, Gopalani S, Hailu A, Horino M, Horita N, Husseini A, Huybrechts I, Inoue M, Islami F, Jakovljevic M, James S, Javanbakht M, Jee SH, Kasaeian A, Kedir MS, Khader YS, Khang YH, Kim D, Leigh J, Linn S, Lunevicius R, El Razek HMA, Malekzadeh R, Malta DC, Marcenes W, Markos D, Melaku YA, Meles KG, Mendoza W, Mengiste DT, Meretoja TJ, Miller TR, Mohammad KA, Mohammadi A, Mohammed S, Moradi-Lakeh M, Nagel G, Nand D, Le Nguyen Q, Nolte S, Ogbo FA, Oladimeji KE, Oren E, Pa M, Park EK, Pereira DM, Plass D, Qorbani M, Radfar A, Rafay A, Rahman M, Rana SM, Soreide K, Satpathy M, Sawhney M, Sepanlou SG, Shaikh MA, She J, Shiue I, Shore HR, Shrime MG, So S, Soneji S, Stathopoulou V, Stroumpoulis K, Sufiyan MB, Sykes BL, Tabares-Seisdedos R, Tadese F, Tedla BA, Tessema GA, Thakur JS, Tran BX, Ukwaja KN, Uzochukwu BSC, Vlassov VV, Weiderpass E, Wubshet Terefe M, Yebyo HG, Yimam HH, Yonemoto N, Younis MZ, Yu C, Zaidi Z, Zaki MES, Zenebe ZM, Murray CJL, Naghavi M. Global, Regional, and National Cancer Incidence, Mortality, Years of Life Lost, Years Lived With Disability, and Disability-Adjusted Life-years for 32 Cancer Groups, 1990 to 2015: A Systematic Analysis for the Global Burden of Disease Study. JAMA Oncol 2017; 3 :524-48.

2. Disease GBD, Injury I, Prevalence C. Global, regional, and national incidence, prevalence, and years lived with disability for 310 diseases and injuries, 1990-2015: a systematic analysis for the Global Burden of Disease Study 2015. Lancet 2016; $388: 1545-602$.

3. Carter BW, Bhosale PR, Yang WT. Immunotherapy and the role of imaging. Cancer 2018; 124 :2906-22.

4. Arina A, Gutiontov SI, Weichselbaum RR. Radiotherapy and immunotherapy for cancer: From "systemic" to "multi-site". Clin Cancer Res 2020.

5. Griniatsos J, Trafalis D. Di ff erences in gastric cancer surgery outcome between East and West: di ff erences in surgery or di ff erent diseases? J BUON 2018; 23 :1210-5.

6. Li Q, Lv M, Jiang H, Wang Y, Yu S, Li W, Yu Y, Liu T. A prospective observational study on the optimal maintenance strategy in HER2-positive advanced gastric cancer treated with trastuzumab-based therapy. J Cancer Res Clin Oncol 2020; $146: 287-95$.

7. Crew KD, Neugut AI. Epidemiology of gastric cancer. World J Gastroenterol 2006; 12 :354-62.

8. Landskron G, De la Fuente M, Thuwajit P, Thuwajit C, Hermoso MA. Chronic inflammation and cytokines in the tumor microenvironment.J Immunol Res 2014; 2014 :149185. 
9. Hoare A, Soto C, Rojas-Celis V, Bravo D. Chronic Inflammation as a Link between Periodontitis and Carcinogenesis. Mediators Inflamm 2019; 2019 :1029857.

10. Karki R, Kanneganti TD. Diverging inflammasome signals in tumorigenesis and potential targeting. Nat Rev Cancer 2019;19:197-214.

11. Galon J, Pages F, Marincola FM, Angell HK, Thurin M, Lugli A, Zlobec I, Berger A, Bifulco C, Botti G, Tatangelo F, Britten CM, Kreiter S, Chouchane L, Delrio P, Arndt H, Asslaber M, Maio M, Masucci GV, Mihm M, Vidal-Vanaclocha F, Allison JP, Gnjatic S, Hakansson L, Huber C, Singh-Jasuja H, Ottensmeier C, Zwierzina H, Laghi L, Grizzi F, Ohashi PS, Shaw PA, Clarke BA, Wouters BG, Kawakami Y, Hazama S, Okuno K, Wang E, O’Donnell-Tormey J, Lagorce C, Pawelec G, Nishimura MI, Hawkins R, Lapointe R, Lundqvist A, Khleif SN, Ogino S, Gibbs P, Waring P, Sato N, Torigoe T, Itoh K, Patel PS, Shukla SN, Palmqvist R, Nagtegaal ID, Wang Y, D'Arrigo C, Kopetz S, Sinicrope FA, Trinchieri G, Gajewski TF, Ascierto PA, Fox BA. Cancer classification using the Immunoscore: a worldwide task force. J Transl Med 2012; $10: 205$.

12. Galon J, Pages F, Marincola FM, Thurin M, Trinchieri G, Fox BA, Gajewski TF, Ascierto PA. The immune score as a new possible approach for the classification of cancer. J Transl Med 2012;10:1.

13. Chia NY, Tan P. Molecular classification of gastric cancer.Ann Oncol 2016; 27 :763-9.

14. Hu J, Wang N, Yang Y, Ma L, Han R, Zhang W, Yan C, Zheng Y, Wang X. Diagnostic value of alphafetoprotein combined with neutrophil-to-lymphocyte ratio for hepatocellular carcinoma. BMC Gastroenterol $2018 ; 18: 186$.

15. Sia D, Jiao Y, Martinez-Quetglas I, Kuchuk O, Villacorta-Martin C, Castro de Moura M, Putra J, Camprecios G, Bassaganyas L, Akers N, Losic B, Waxman S, Thung SN, Mazzaferro V, Esteller M, Friedman SL, Schwartz M, Villanueva A, Llovet JM. Identification of an Immune-specific Class of Hepatocellular Carcinoma, Based on Molecular Features.Gastroenterology 2017; 153 :812-26.

16. Diem S, Schmid S, Krapf M, Flatz L, Born D, Jochum W, Templeton AJ, Fruh M. Neutrophil-toLymphocyte ratio (NLR) and Platelet-to-Lymphocyte ratio (PLR) as prognostic markers in patients with non-small cell lung cancer (NSCLC) treated with nivolumab. Lung Cancer 2017;111:176-81.

17. Wang D, Bai N, Hu X, OuYang XW, Yao L, Tao Y, Wang Z. Preoperative inflammatory markers of NLR and PLR as indicators of poor prognosis in resectable HCC. PeerJ 2019; 7 :e7132.

18. Lee BM, Chung SY, Chang JS, Lee KJ, Seong J. The Neutrophil-Lymphocyte Ratio and PlateletLymphocyte Ratio Are Prognostic Factors in Patients with Locally Advanced Pancreatic Cancer Treated with Chemoradiotherapy. Gut Liver 2018; $12: 342-52$.

19. Dolan RD, McSorley ST, Park JH, Watt DG, Roxburgh CS, Horgan PG, McMillan DC. The prognostic value of systemic inflammation in patients undergoing surgery for colon cancer: comparison of composite ratios and cumulative scores. Br J Cancer 2018; 119 :40-51.

20. Choi Y, Kim JW, Nam KH, Han SH, Kim JW, Ahn SH, Park DJ, Lee KW, Lee HS, Kim HH. Systemic inflammation is associated with the density of immune cells in the tumor microenvironment of gastric cancer.Gastric Cancer 2017; 20 :602-11.

21. Chen DS, Mellman I. Elements of cancer immunity and the cancer-immune set point. Nature 2017; 541 :321-30.

22. Giraldo NA, Becht E, Vano Y, Petitprez F, Lacroix L, Validire P, Sanchez-Salas R, Ingels A, Oudard S, Moatti A, Buttard B, Bourass S, Germain C, Cathelineau X, Fridman WH, Sautes-Fridman C. TumorInfiltrating and Peripheral Blood T-cell Immunophenotypes Predict Early Relapse in Localized Clear Cell Renal Cell Carcinoma. Clin Cancer Res 2017; 23 :4416-28. 
23. Wang FH, Shen L, Li J, Zhou ZW, Liang H, Zhang XT, Tang L, Xin Y, Jin J, Zhang YJ, Yuan XL, Liu TS, Li GX, Wu Q, Xu HM, Ji JF, Li YF, Wang X, Yu S, Liu H, Guan WL, Xu RH. The Chinese Society of Clinical Oncology (CSCO): clinical guidelines for the diagnosis and treatment of gastric cancer. Cancer Commun (Lond) 2019; $39: 10$.

24. Zong L, Abe M, Seto Y, Ji J. The challenge of screening for early gastric cancer in China. Lancet 2016; $388: 2606$.

25. Hanyu T, Wakai A, Ishikawa T, Ichikawa H, Kameyama H, Wakai T. Carcinoma in the Remnant Stomach During Long-Term Follow-up After Distal Gastrectomy for Gastric Cancer: Analysis of Cumulative Incidence and Associated Risk Factors. World J Surg 2018; 42 :782-7.

26. Luke JJ, Flaherty KT, Ribas A, Long GV. Targeted agents and immunotherapies: optimizing outcomes in melanoma. Nat Rev Clin Oncol 2017; 14 :463-82.

27. Beyar-Katz O, Gill S. Novel Approaches to Acute Myeloid Leukemia Immunotherapy. Clin Cancer Res 2018; 24 :5502-15.

28. Dolcetti R, De Re V, Canzonieri V. Immunotherapy for Gastric Cancer: Time for a Personalized Approach? Int J Mol Sci 2018; 19 .

29. Farkona S, Diamandis EP, Blasutig IM. Cancer immunotherapy: the beginning of the end of cancer? BMC Med 2016; $14: 73$.

30. Smyth EC, Cunningham D. Encouraging results for PD-1 inhibition in gastric cancer. Lancet Oncol 2016; $17: 682-3$.

31. Engelhard VH, Rodriguez AB, Mauldin IS, Woods AN, Peske JD, Slingluff CL, Jr. Immune Cell Infiltration and Tertiary Lymphoid Structures as Determinants of Antitumor Immunity. J Immunol 2018;200 :432-42.

32. Zhou L, Chong MM, Littman DR. Plasticity of CD4+ T cell lineage differentiation. Immunity 2009; 30 :646-55.

33. Zander R, Schauder D, Xin G, Nguyen C, Wu X, Zajac A, Cui W. CD4(+) T Cell Help Is Required for the Formation of a Cytolytic CD8(+) T Cell Subset that Protects against Chronic Infection and Cancer.Immunity $2019 ; 51: 1028-42$ e4.

34. Groves CJ, Carrell J, Grady R, Rajan B, Morehouse CA, Halpin R, Wang J, Wu J, Shrestha Y, Rayanki R, Kolbeck R, Wang Y, Herbst R. CD19-positive antibody-secreting cells provide immune memory.Blood Adv 2018; 2 :3163-76.

35. Schioppa T, Moore R, Thompson RG, Rosser EC, Kulbe H, Nedospasov S, Mauri C, Coussens LM, Balkwill FR. B regulatory cells and the tumor-promoting actions of TNF-alpha during squamous carcinogenesis. Proc Natl Acad Sci U S A 2011;108:10662-7.

36. Gu Y, Liu Y, Fu L, Zhai L, Zhu J, Han Y, Jiang Y, Zhang Y, Zhang P, Jiang Z, Zhang X, Cao X. Tumor-educated B cells selectively promote breast cancer lymph node metastasis by HSPA4-targeting IgG. Nat Med 2019; $25: 312-22$.

37. Nikolich-Zugich J. The twilight of immunity: emerging concepts in aging of the immune system. Nat Immunol 2018; 19 :10-9.

38. Castelo-Branco C, Soveral I. The immune system and aging: a review. Gynecol Endocrinol 2014; 30 $: 16-22$.

Table 1 Patient characteristics 


\begin{tabular}{|c|c|c|}
\hline Variables & Number of patients & Percentage \\
\hline Variables & Number of patients & Percentage \\
\hline \multicolumn{3}{|l|}{ Sex } \\
\hline Male & 166 & 76.1 \\
\hline Female & 52 & 23.9 \\
\hline \multicolumn{3}{|l|}{ Age $(\text { years })^{\mathrm{a}}$} \\
\hline$<70$ & 180 & $82.6 ? \gtreqless ?$ \\
\hline 70 & 38 & 17.4 \\
\hline \multicolumn{3}{|l|}{ Borrmann classification $^{\mathrm{b}}$} \\
\hline Type I & 38 & 17.4 \\
\hline Type II & 45 & 20.6 \\
\hline Type III & 89 & 40.8 \\
\hline Type IV & 46 & 21.1 \\
\hline \multicolumn{3}{|l|}{ Vascular invasion } \\
\hline Absent & 132 & 60.6 \\
\hline Present & 86 & 39.4 \\
\hline \multicolumn{3}{|l|}{ Neural invasion } \\
\hline Absent & 82 & 37.6 \\
\hline Present & 136 & 62.4 \\
\hline \multicolumn{3}{|l|}{ TNM stage ${ }^{\mathrm{C}}$} \\
\hline I & 39 & 17.9 \\
\hline II & 58 & 26.6 \\
\hline III & 107 & 49.1 \\
\hline IV & 14 & 6.4 \\
\hline \multicolumn{3}{|c|}{ Lymph node ratio (involved/examined lymph nodes) } \\
\hline 0 & 66 & 30.3 \\
\hline$>0$ to $[?] 0.3$ & 85 & 39.0 \\
\hline$>0.3$ to $[?] 0.6$ & 44 & 20.2 \\
\hline$>0.6$ & 23 & 10.6 \\
\hline \multicolumn{3}{|l|}{ WHO classification } \\
\hline Well to moderately differentiated & 96 & 44.0 \\
\hline Poorly differentiated & 55 & 25.2 \\
\hline Signet ring cell & 54 & 24.8 \\
\hline Mucinous & 13 & 6.0 \\
\hline \multicolumn{3}{|l|}{ Tumor location } \\
\hline Lower third & 143 & 65.6 \\
\hline Middle third & 41 & 18.8 \\
\hline Upper third & 18 & 8.3 \\
\hline Entire stomach & 16 & 7.3 \\
\hline
\end{tabular}

${ }^{a}$ Median age: 61 years, range $30-83$ years.

b Borrmann type I: polyp type; Borrmann type II: local infiltration type; Borrmann type III: ulcer type; Borrmann type IV: diffusely infiltrative type

C Based on the 8th edition of the AJCC Cancer Staging Manual of the American Joint Committee on Cancer.

Table 2 Associations between clinicopathologic variables and systemic inflammatory markers in GC 


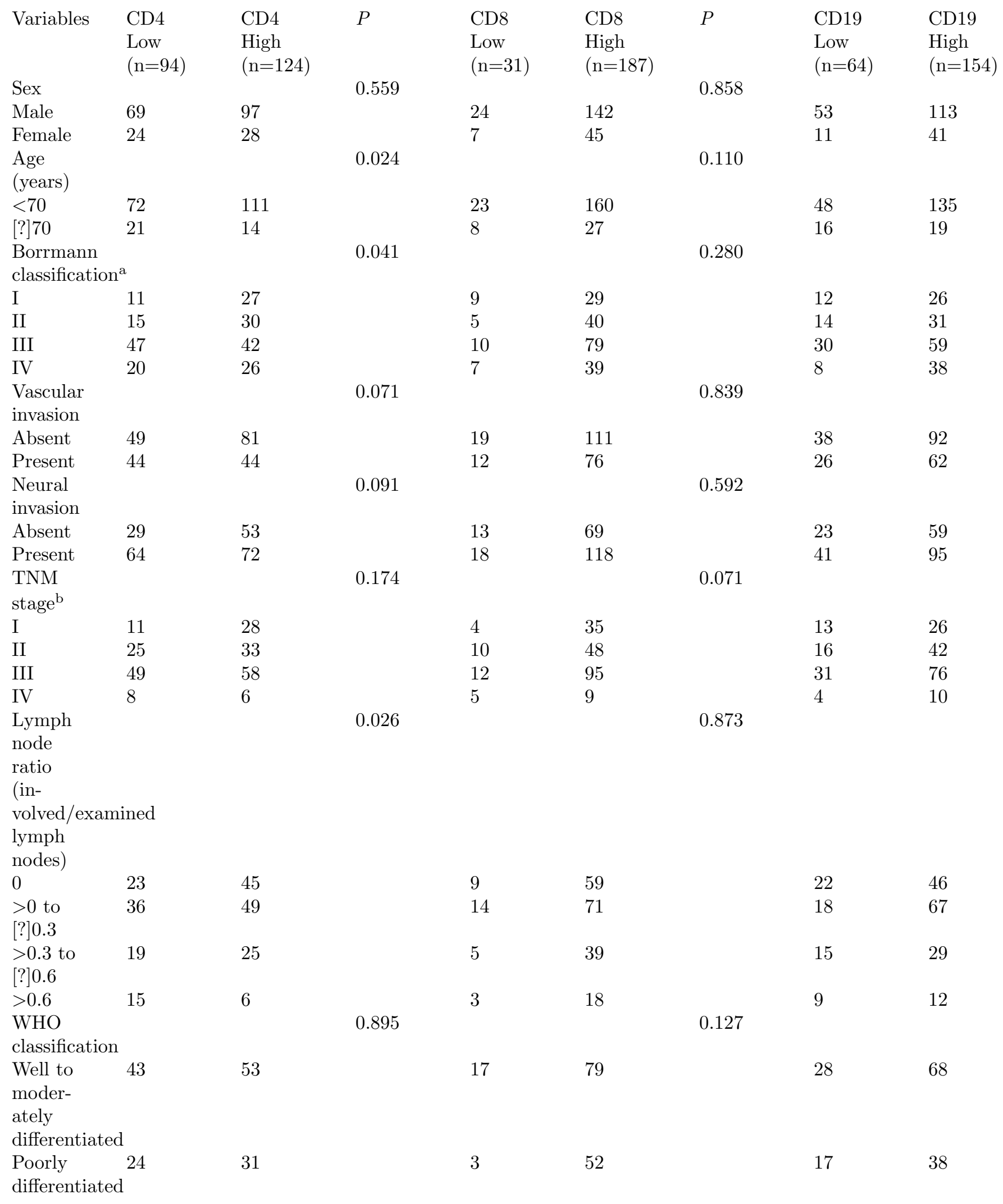




\begin{tabular}{|c|c|c|c|c|c|c|c|c|}
\hline $\begin{array}{l}\text { Signet } \\
\text { ring } \\
\text { cell }\end{array}$ & 21 & 33 & & 10 & 44 & & 14 & 40 \\
\hline Mucinous & 5 & 8 & & 1 & 12 & & 5 & 8 \\
\hline $\begin{array}{l}\text { Tumor } \\
\text { location }\end{array}$ & & & 0.778 & & & 0.071 & & \\
\hline $\begin{array}{l}\text { Lower } \\
\text { third }\end{array}$ & 7 & 11 & & 2 & 16 & & 37 & 106 \\
\hline $\begin{array}{l}\text { Middle } \\
\text { third }\end{array}$ & 18 & 23 & & 2 & 39 & & 14 & 27 \\
\hline $\begin{array}{l}\text { Upper } \\
\text { third }\end{array}$ & 63 & 80 & & 22 & 121 & & 5 & 13 \\
\hline $\begin{array}{l}\text { Entire } \\
\text { stomach }\end{array}$ & 5 & 11 & & 5 & 11 & & 8 & 8 \\
\hline
\end{tabular}

${ }^{a}$ Borrmann type I: polyp type; Borrmann type II: local infiltration type; Borrmann type III: ulcer type; Borrmann type IV: diffusely infiltrative type

b Based on the 8th edition of the AJCC Cancer Staging Manual of the American Joint Committee on Cancer

Table 3 Univariate and multivariate analyses of independent risk factors for death of patients with GC

\begin{tabular}{|c|c|c|c|c|}
\hline Variables & $\begin{array}{l}\text { Univariate analysis }^{\mathrm{a}} \\
\mathrm{HR}\end{array}$ & $\begin{array}{l}\text { Univariate analysis }^{\mathrm{a}} \\
95 \% \text { CI }\end{array}$ & $\begin{array}{l}\text { Univariate analysis }^{\mathrm{a}} \\
P\end{array}$ & $\begin{array}{l}\text { Multivariate analysis }{ }^{b} \\
\text { HR }\end{array}$ \\
\hline Serum CD4 & 0.490 & $0.342-0.701$ & 0.000 & 0.674 \\
\hline Serum CD8 & 0.946 & $0.567-1.579$ & 0.832 & \\
\hline Serum CD19 & 0.644 & $0.445-0.932$ & 0.020 & 0.909 \\
\hline Infiltration of $\mathrm{CD}^{+} \mathrm{T}$ cells & 6.502 & $4.191-10.086$ & 0.000 & 3.262 \\
\hline Infiltration of $\mathrm{CD}^{+} \mathrm{T}$ cells & 0.201 & $0.135-0.301$ & 0.000 & 0.443 \\
\hline Infiltration of $\mathrm{CD} 19^{+} \mathrm{B}$ cells & 6.104 & $4.000-9.315$ & 0.000 & 3.262 \\
\hline
\end{tabular}

${ }^{\text {a }}$ Log rank test was used for univariate analysis.

b Cox regression model was used for multivariate analysis.
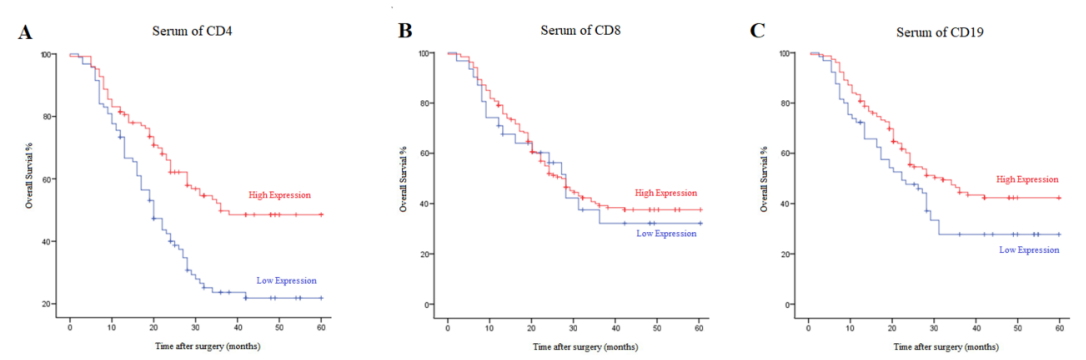

Fig. 1 Overall survival of patients with GC stratified by the systemic inflammatory markers CD4, CD8 and CD19. 

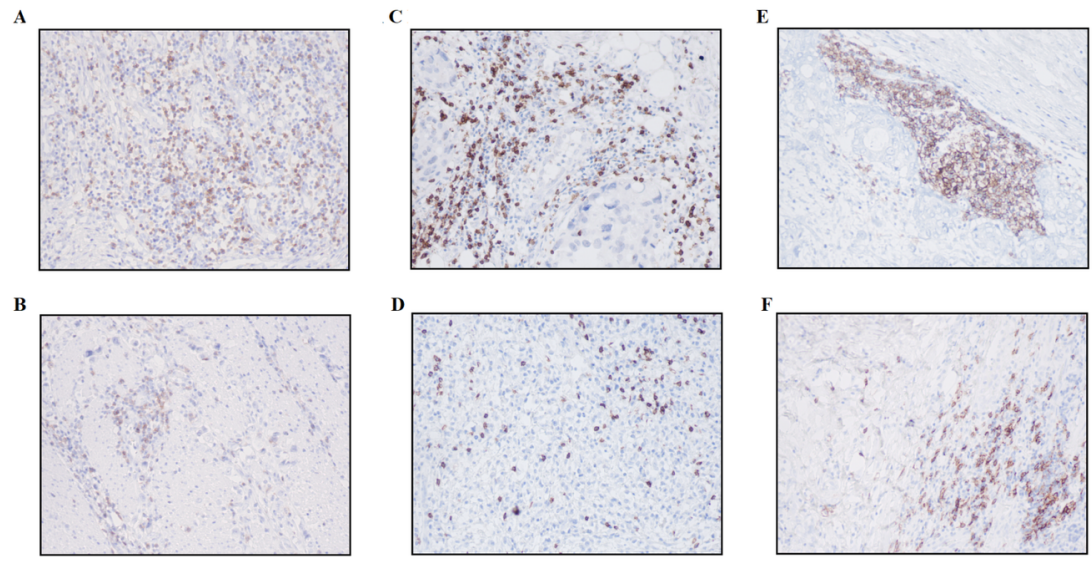

Fig. 2 Immunohistochemistry of $\mathrm{CD} 4^{+} \mathrm{T}, \mathrm{CD} 8^{+} \mathrm{T}$ and $\mathrm{CD} 19^{+} \mathrm{B}$ cells in $\mathrm{GC}$ paraffin sections. A: high infiltration of $\mathrm{CD} 4^{+} \mathrm{T}$ cells; B: low infiltration of $\mathrm{CD} 4^{+} \mathrm{T}$ cells; C: high infiltration of $\mathrm{CD} 8^{+} \mathrm{T}$ cells; D: low infiltration of $\mathrm{CD} 8^{+} \mathrm{T}$ cells; E: high infiltration of $\mathrm{CD} 19^{+} \mathrm{B}$ cells; F: low infiltration of $\mathrm{CD} 19^{+} \mathrm{B}$ cells.
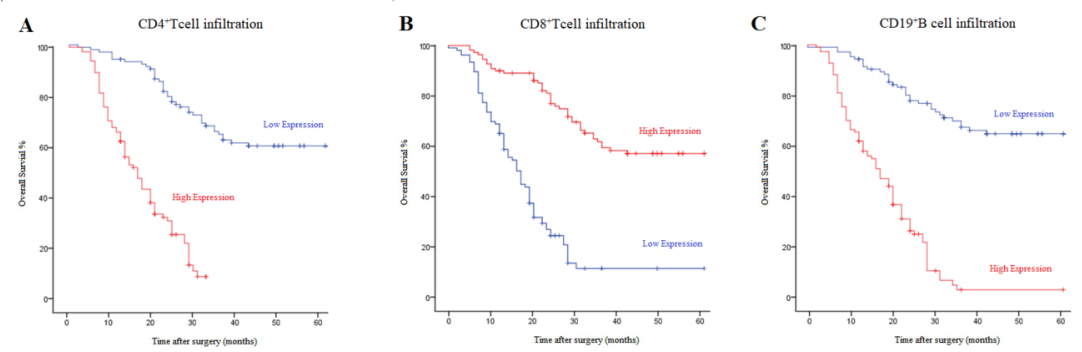

Fig. 3 Overall survival of patients with GC stratified by infiltration of immune cells in the tumor microenvironment.
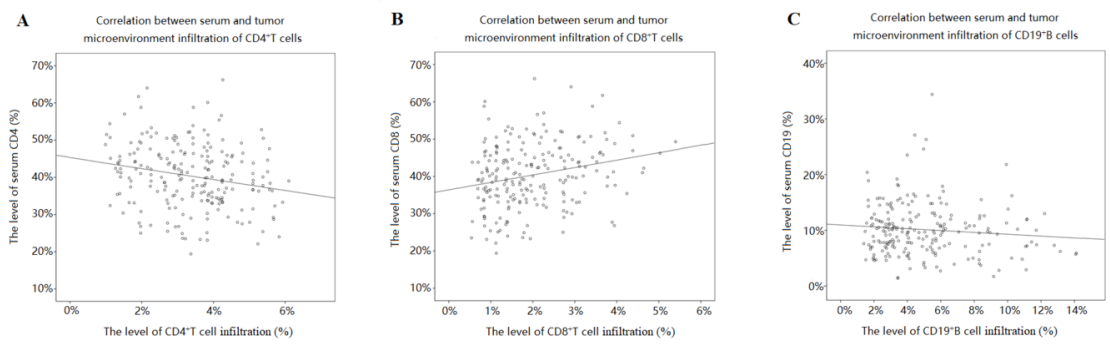

Fig. 4 Correlations between serum CD4, CD8, CD19 and infiltration of immune cells in the tumor microenvironment. 